\title{
BORE-HOLE VIDEO AND PHOTOGRAPHIC CAMERAS
}

\author{
by
}

\author{
R. M. Koerner, D. A. Fisher and M. Parnandi
}

(Polar Continental Shelf Project, Energy, Mines and Resources Canada, City Centre Tower, 4th Floor, 880 Wellington Street, Ottawa, Ontario K1A OE4, Canada)

\section{ABSTRACT}

$35 \mathrm{~mm}$ still and television techniques are shown to be of great value in following changes at the bedrock/ice interface and along borehole walls during closure over one or more years in polar or sub-polar ice caps. We have found no evidence of basal slip over a one year period in a $137 \mathrm{~m}$ hole at the top of the flow line on an ice cap in northern Ellesmere Island. However, the bore hole has deformed to an elliptical cross-section near the bed and some pronounced extrusion-like layers have developed within $3 \mathrm{~m}$ of the bed in dirty ice in the year since drilling.

\section{INTRODUCTION}

The purpose of this paper is, in part, to draw attention to the importance of bore-hole measurements in which photography can play a very important role. While the potential of bore-hole photography in deformation studies has already been shown by Harrison and Kamb (1973) it is apparent to us that not only has insufficient use been made by others of photographic techniques in down bore-hole studies but that of the very many bore holes drilled so far in the polar regions very few have been used to study the bed/ice relationship or ice dynamics problems. Paterson's work is perhaps one of the most notable exceptions here (Paterson, 1976 and 1977).

\section{STILL PHOTOGRAPHY}

The main advantage of still photography over television is its better resolution. In addition, enlargement of any part of a negative can be made and, wherever necessary, stereo pairs can be taken following Harrison and Kamb's (1973) procedures.

Our techniques for still photography are very simple but yield satisfactory results in terms of bottom and wall photography in dry holes. For studies in 1977, the shutter of a Minolta $35 \mathrm{~mm}$ camera was mechanically triggered. The mechanical device consisted of a long hollow tube with a slider attached to a conventiona? cable release. When the tube touched bedrock the slider moved up the tube to contact the cable release and triggered the shutter mechanism. An electronic flash was dismantled and the bulb attached to the front of the camera next to the lens with the electronics mounted behind the camera. The entire package was mounted on the end of a CRREL thermal drill. To avoid damaging the camera the last metre or so of the descent was achieved with the low- gear manual control of the winch. Marks made on the drill cable during drilling allowed a sufficiently accurate measurement of camera depth to be made during the triggering process. In addition, the front-mounted triggering device allowed precise focusing. An example of one of these photographs taken at $337 \mathrm{~m}$ depth appears in Figure 1 .

In 1980 we needed a smaller camera to inspect a hole after one year of bore-hole closure. The initial $163 \mathrm{~mm}$ diameter of the 1979 hole had a year later closed to a minimum diameter of $144 \mathrm{~mm}, 2.8 \mathrm{~m}$ above the bed. We wished to put a

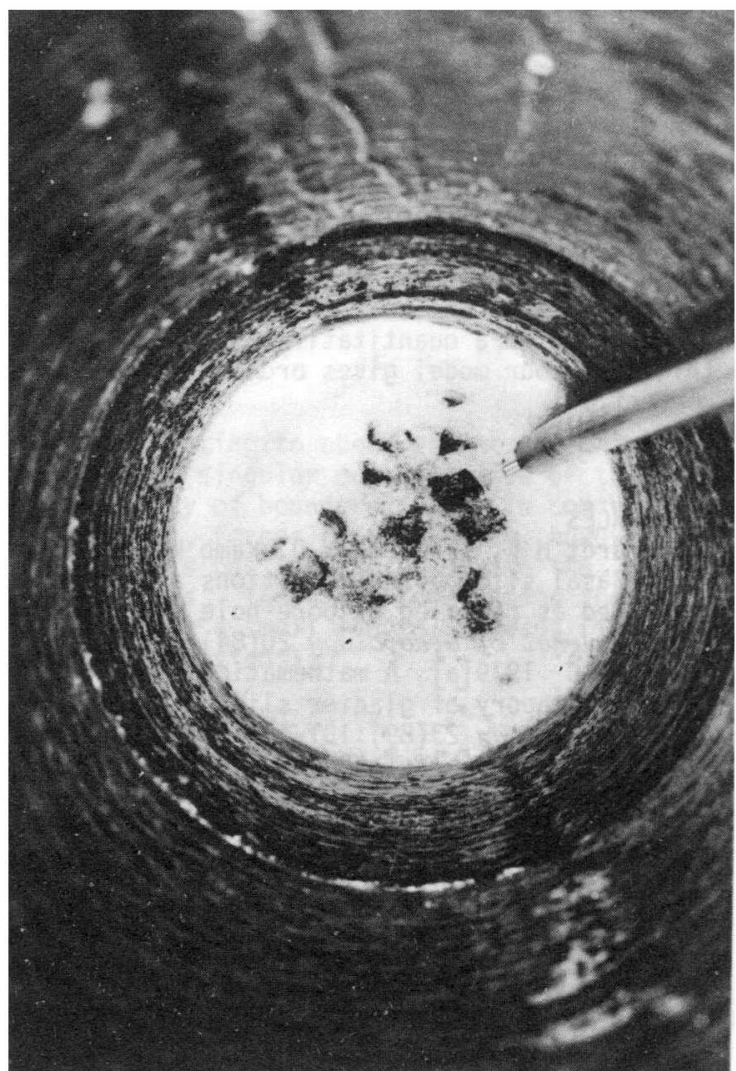

Fig. 1. Photograph of bed and bottom of bore hole on Agassiz ice cap, northern Ellesmere Island, at $337 \mathrm{~m}$ depth. Darker vertical 1 ines on top left- and lower right-hand sides of photograph are due to melting by heated melt tubes in thermal drill. 
camera within $200 \mathrm{~mm}$ of the bed so that it had to pass through the narrowest part of the hole. In this case a Voigtlander $35 \mathrm{~mm}$ camera was used. The shutter was triggered with a $24 \mathrm{~V}$ solenoid. An arm was welded to the solenoid core and attached to an eye-bolt threaded into the camera release button. The flash bulb was again mounted separately next to the camera lens.

This arrangement suffered from imprecise focusing. Considerable care has to be taken to determine the camera position relevant to the bedrock bottom of the bore hole. We had already made caliper (diameter) measurements down the bore hole prior to photography and marked the cable at potentially interesting depths where the diameters were unusually large or sma11. The same cable was used for photography. Without the caliper method some vertical strain measurements are essential if repeated photography of features is planned at such time intervals that vertical strain changes the surface-to-depth increment.

\section{TELEVISION SYSTEM}

Television has the distinct advantage over a still camera of giving an immediate picture. Scanning of features can be made and recorded on video tape. Specifications for our television equipment are shown in Table I. Basically it consists of a vidicom tube with the electronics

TABLE $I_{\text {O }}$ SPECIFICATIONS OF THE UNDER-WATER BORE-HOLE TELEVISION CAMERA (DR 6-C)

\begin{tabular}{|c|c|}
\hline Dimensions & $\begin{array}{l}\text { Length: } \quad 711 \mathrm{~mm} \\
\text { Diameter : } 62.4 \mathrm{~mm} \\
\text { Weight: } \quad 2.5 \mathrm{~kg} \text { (in air) }\end{array}$ \\
\hline $\begin{array}{l}\text { Optical } \\
\text { specifications }\end{array}$ & $\begin{array}{l}\text { Rebikoff-Ivanoff S-101-B } \\
\text { fully-corrected lens with } \\
\text { special design Angenieux } \\
\text { R-3 } 9.5 \mathrm{~mm} F: 2.2 \\
\text { Diagonal angle in water } 69^{\circ} \text {, } \\
\text { in air } 91^{\circ} \text {. Diameter } 62.4^{\circ} \\
\mathrm{mm}\end{array}$ \\
\hline Depth of field & $\begin{array}{l}\text { Lens contact to near- } \\
\text { infinity without focusing }\end{array}$ \\
\hline $\begin{array}{l}\text { Environmental } \\
\text { specifications }\end{array}$ & $\begin{array}{l}\text { Operating temperature range } \\
-50 \text { to }+45^{\circ} \mathrm{C} \text {. Maximum op- } \\
\text { erating depth } 450 \mathrm{~m} \text {. }\end{array}$ \\
\hline Resolution & $\begin{array}{l}\text { Horizontal resolution is } \\
\text { over } 400 \text { lines at centre }\end{array}$ \\
\hline $\begin{array}{l}\text { Dynamic light } \\
\text { range }\end{array}$ & $\begin{array}{l}\text { Automatic sensitivity } \\
\text { permits } 10 \text { to } 10000 \text { or } 1 \\
\text { to } 1000 \text { dynamic range }\end{array}$ \\
\hline Grey shades (no.) & Ten (10) \\
\hline Camera tube type & $\begin{array}{l}\text { Vidicon } 8929 \text { with rugge- } \\
\text { dized magnetic deflection }\end{array}$ \\
\hline $\begin{array}{l}\text { Signal-to-noise } \\
\text { ratio }\end{array}$ & $42 \mathrm{~dB}$ \\
\hline Video output & $\begin{array}{l}1 \text { volt peak-to-peak compo- } \\
\text { site video signal with } \\
\text { negative sync. } 75 \text { ohris } \\
\text { unbalanced }\end{array}$ \\
\hline Cable & RG 11 \\
\hline Pressure & $\begin{array}{l}\text { Capable of immersion in } \\
\text { water to } 450 \mathrm{~m} \text { depth }\end{array}$ \\
\hline
\end{tabular}

packaged in a case capable of withstanding water pressures obtaining at $450 \mathrm{~m}$ depth. To date we have used the television system only in a dry hole down to a depth of $137 \mathrm{~m}$. With a mirror it has also been used to examine the walls of the same bore hole particularly where there are dirt layers.

The enclosed lighting system proved inadequate and in 1979 a $110 \mathrm{~V}$ AC movie light was attached above the camera. In 1980, to avoid using an extra cable for lighting, twe lve $6-v$ flashlight bulbs were mounted around the lens end of the camera. These bulbs were powered by a battery pack (C-cells) strapped to the cable above the camera unit.

The mirror provided with the camera was designed to allow side- and forward-viewing simultaneously. The side view occupied only a small part of the monitor screen. This had very little advantage and was replaced in 1980 with a larger mirror capable of filling almost the entire monitor screen. The same mirror was also used for still photography.

\section{BORE-HOLE PREPARATION}

For visual inspection and accurate strain determination, it is essential to clean up the bottom of the bore hole. This is because movement of the drill or any other instrument down the hole causes chips of firn to break off the uppermost 20 to $30 \mathrm{~m}$ of the hole. These chips collect at the bottom to cover the bedrock features. The bottom can be cleaned up with the drill itself although this is not a completely satisfactory technique. The drill is set on the bottom of the bore hole with both heat and vacuum pump on for several minutes. It is then raised with the heat off and the pump on and left suspended for 10 min. Finally, the drill is set back on the bottom with the heat off but the pump still on to draw up any melt water that has collected there from the walls. This removes the ice chips but can cause more chips to fall when the drill is brought up after the clean-up operation. A better method of hole clean-up involves the use of alcohol to absorb ice or firn chips. A plastic bag containing about one litre of alcohol, and open at the top, is lowered down the bore hole until it collapses on the bottom. The alcohol is left for $30 \mathrm{~min}$. An absorbent material (diapers and sanitary towels) wrapped in an absorbent cloth is then lowered down the hole on the end of a $1 \mathrm{~kg}$ weight. This is left down for $10 \mathrm{~min}$, and moved up and down several times. By measuring both the amount of alcohol put in the hole and the alcohol, together with the absorbed chips squeezed out from the absorbing material on extraction, one can get a reasonable estimate of when the hole is free of chips and is dry. We found the alcohol method the better one of the two, as a comparison of Figures 1 and 2 show. The drill technique is obviously not usable after the first year due to bore-hole closure.

\section{RESULTS AND DISCUSSION}

Thermal drilling rates in cold ice can be affected by many types of malfunction such as inadequate suction to remove the melt water, heating-element failure, and incorrect cable tension. In addition, the presence of even a small (less than $100 \mathrm{~mm}^{2}$ ) fragment of plastic or wood, etc., can bring drilling to a standstill, or cause slow drilling rates which produce small diameter cores. Television is particularly useful in determining if the cause for slow drilling is sediment-laden ice or material lying on the bore-hole bottom. The right steps can then be taken to correct the problem. 
We have also used video equipment in the course of vertical-strain measurements necessary to derive a time scale for cores (Paterson and others 1977). It is essential in the surfaceto-bed measurement of total vertical strain to ensure there is no ice debris on the bed. This debris is derived from instruments breaking off loose firn each time they are lowered down or raised up the hole after drilling is complete. This often happens during inclinometer, borehole diameter, or temperature measurements. The only way to ensure that one is measuring to the bed from the surface is with video equipment. We are now using a laser-ranger to bounce light off a mirror placed on the bed. Direct inspection with video equipment ensures proper emplacement of the mirror.

We have used photographic and video equipment principally to examine very dirty layers found in basal ice at the top of the flow line of the Agassiz ice cap, northern Ellesmere Island, Northwest Territories, Canada, in 1979: Drilling in dirty ice with a thermal drill is very slow ( $2.75 \mathrm{~m}$ in $16 \mathrm{~h}$ ) so. that the core melts before extraction. The only way then to determine the nature of the basal dirt layers and how they, and the enclosing ice, deform is with the use of video equipment.

We now discuss some examples of still photography and television recordings (by means of Polaroid photographs of the TV screen monitor). Figure 1 is of the bed at the bottom of a $337 \mathrm{~m}$ hole drilled on Agassiz ice cap in 1977. An earlier photograph showed that a $300 \mathrm{~mm}$ long core had been left at the bottom of the bore hole. This was recovered but without photography no attempt to recover the core would have been made as it would have been considered to have melted while the drill rested on the bed.

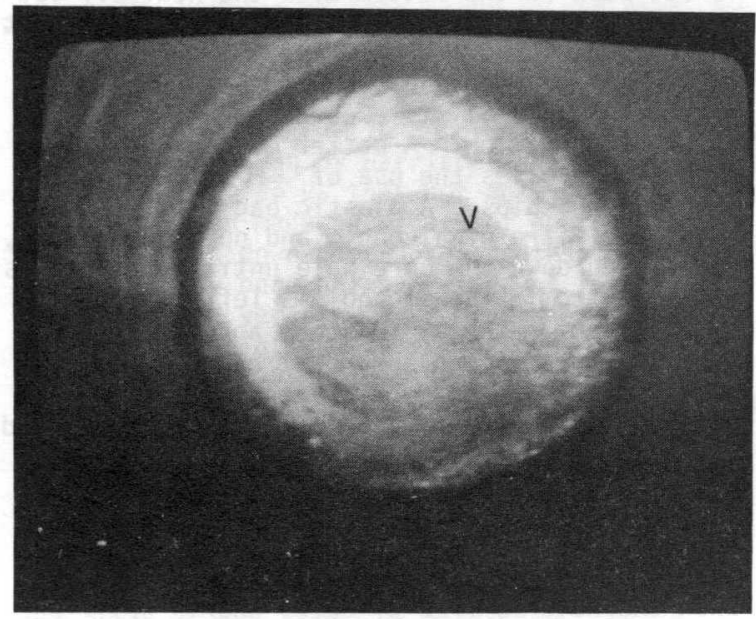

Fig.2. Photograph of bed at bottom of 1979 bore hole at $137 \mathrm{~m}$ depth. (Polaroid photograph of TV screen.)

Figure 2 shows the bottom of the bore hole shortly after drilling in 1979. The ring is the result of an impression made in the basal material by the drill when intentionally allowed to free-drop from a height of $1 \mathrm{~m}$ above the bed. The impression collected excess melt water after drill removal to give a highly reflective surface.

Figure 3 is a close-up of the bed in hole 79. Several stones are evident, lying on what we consider a generally clayey bed.

Figures 4 and 5 are of the bed of hole 79 taken in 1980, a year after drilling and after alcohol clean-up. Several of the same features

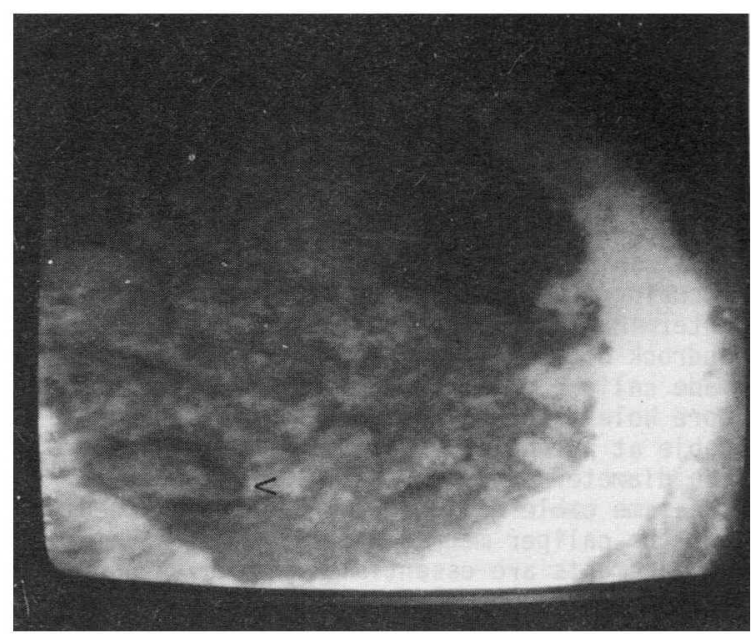

Fig.3. Close-up photograph of bed at bottom of 1979 bore hole at $137 \mathrm{~m}$ depth. Arrow points to stone used as marker to orient each picture. (Polaroid photograph of TV screen.)

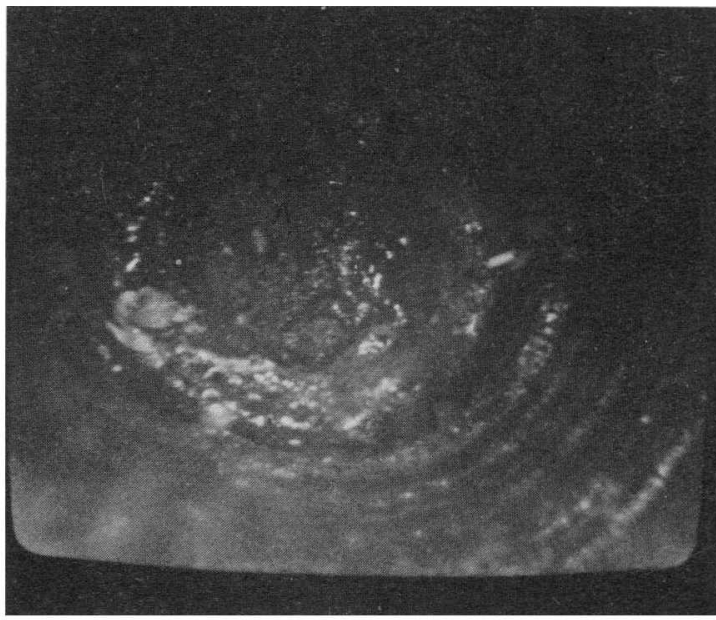

Fig.4. Photograph of bed in 1979 bore hole one year after drilling and after clean-up operations. Arrow points to marker stone used for picture orientation. (Polaroid photograph of TV screen.)

are evident including the striated stone marked by an arrow. The dark ice band is common to all the photographs. The dark colour of this band is largely due to the hole being wider at this level (see also Fig.1) and therefore receiving and reflecting less light. The grey ring has gone, however, and is replaced by only a very faint image of the original depression. We conclude that the highly reflective refrozen meltwater infilling of the drill impression has been removed by the alcohol. One item of great interest, which we will continue to monitor in future years, is that after one year the hole can be seen to have changed to an elliptical shape (cf.Figs. 4 and 5 with Fig-3). Evidently we did not drill exactly at the top of the flow line.

Figure 6 is a TV screen photograph from 3 $m$ above the bed. The white rings are reflections from shoulders in the hole. The shoulders are due to increased drill rates as we enter cleaner ice. Some firn chips from higher up the bore hole have collected on the shoulders. 


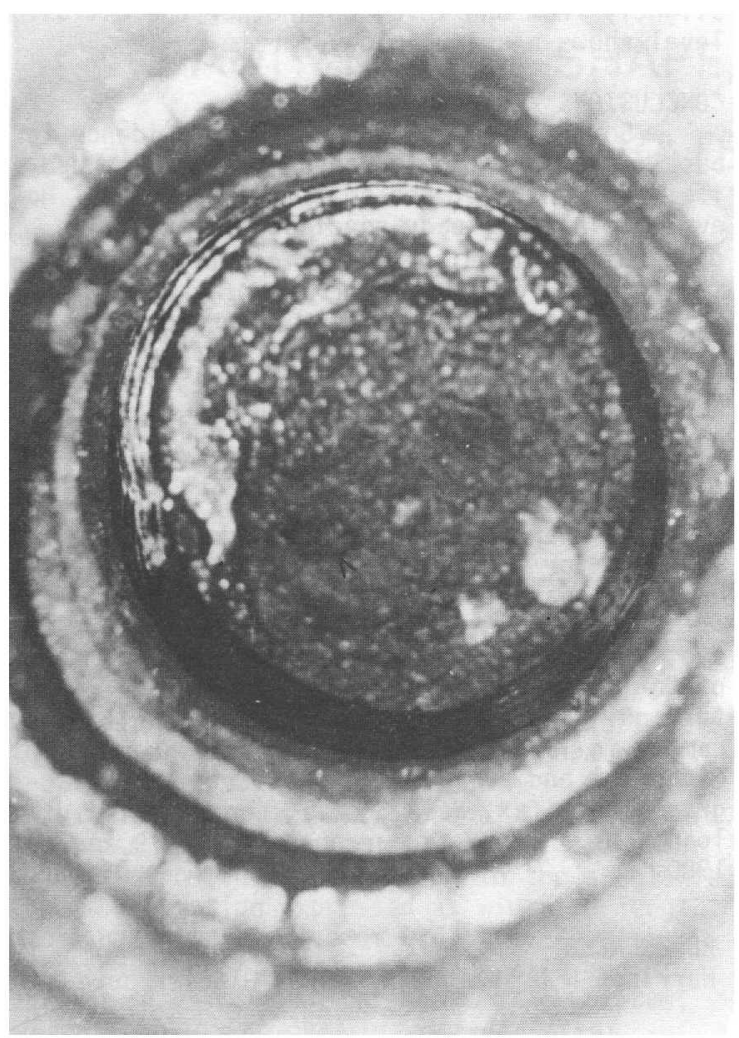

Fig.5. Photograph of bed in 1979 bore hole one year after drilling and after alcohol clean-up operations. Arrow points to marker stone used for picture orientation.

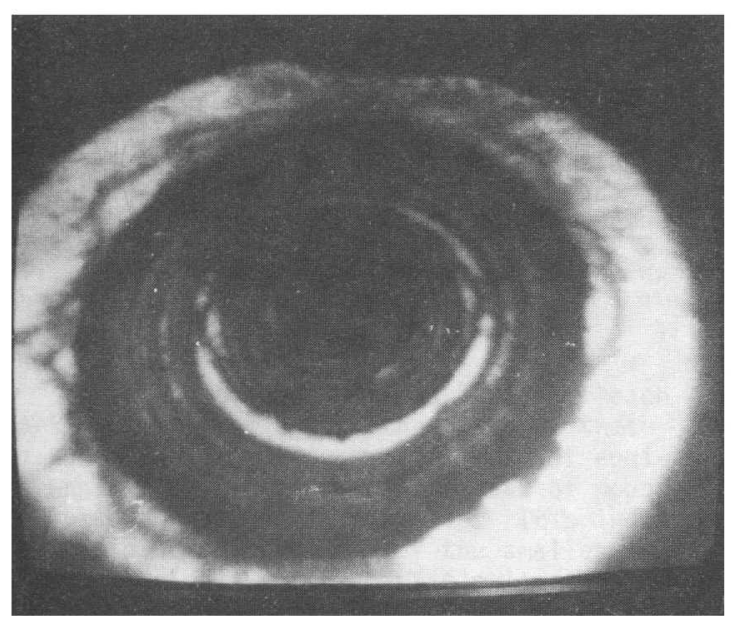

Fig.6. View down bore hole from $3 \mathrm{~m}$ above bed. Lighter-coloured circles are shoulders in hole where drilling rates increase and bore-hole diameter decreases downwards. (Polaroid photograph of TV screen.)

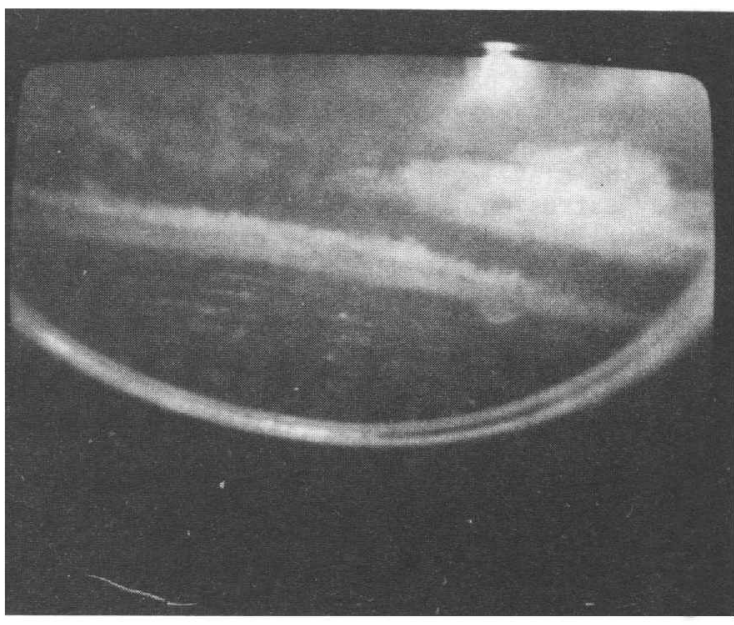

Fig.7. Side view, using mirror, of clean-ice/ dirty-ice boundary. Light-coloured layers are of ice with high clay fraction. Note ribbed appearance of ice where low drilling rates prevailed. (Polaroid photograph of TV screen.)

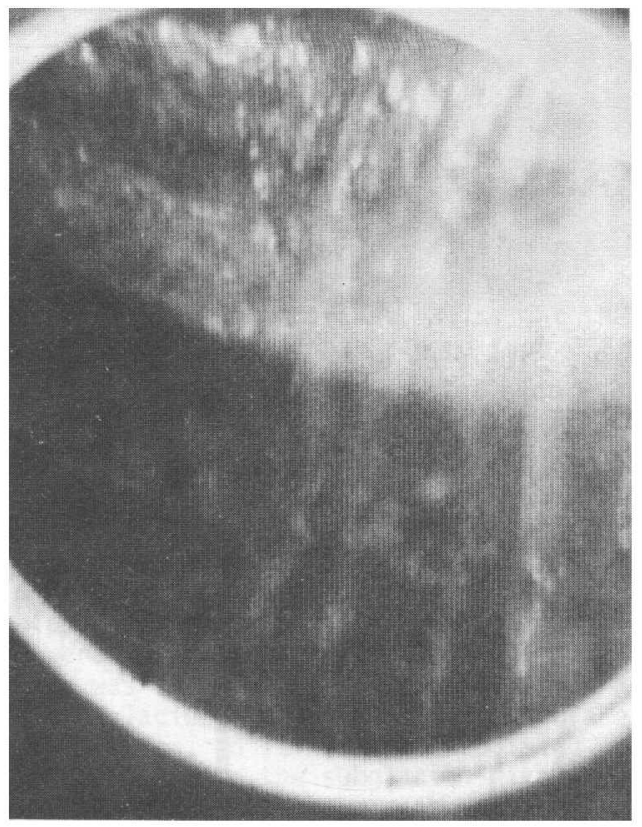

Fig.8. Banded ice in 1979 bore hole $2 \mathrm{~m}$ above the bed. Light-coloured ice has a high clay fraction. Vertical runnels are formed by melt water (caused by the drill suction tubes during slow drilling) refreezing as it runs down bore-hole walls. 
We now examine the side-view pictures taken in May 1980. Figure 7 shows what we first considered to be bedrock because the drill remained at the same level with the heat on for 10 min. The upper half of the mirror image is of clean ice and the lower half of dirty ice showing the ribbed pattern characteristic of extremely slow drilling rates. The light-coloured band is a clay-rich layer. The light-coloured lens above the clay layer may be a clay-rich lens or a clay extrusion. This photograph suggests that slow drilling rates below the clay-rich layer may have been due to clay sediments from this layer remaining at the drill-ice interface. The ice itself does not seem dirty in our video recordings.

Figure $B$ is a close-up photo of the mirror portion of the TV picture. It shows a light (clayey ice?) layer over a dark (clean ice?) layer with lines of refrozen melt water running across both layers. The refrozen melt was generated by the heated melt-water suction tubes running up the inside of the drill. Melting of the walls by these tubes is usually minimal during normal drilling (see, for example, Fig.l at approximately the 8 and $20^{\prime}$ clock positions) Figure 9 shows an extrusion layer consis-

ting of rounded ice grains attached to what might be a thin clay-rich layer at its base. Caliper measurements at the same distance above bedrock (Fig.10) show that the extrusion now forms the

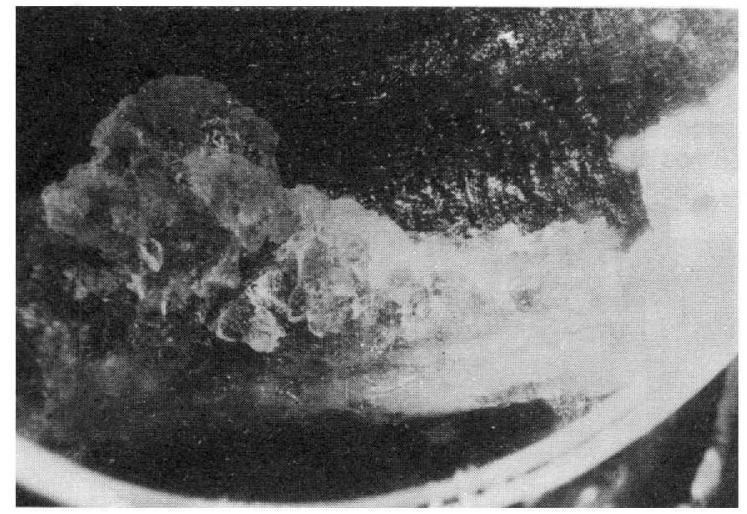

Fig.9. Side view of ice extrusion from wall of 1979 bore hole taken in 1980 one year after drilling. $1 \mathrm{~m}$ above bed.

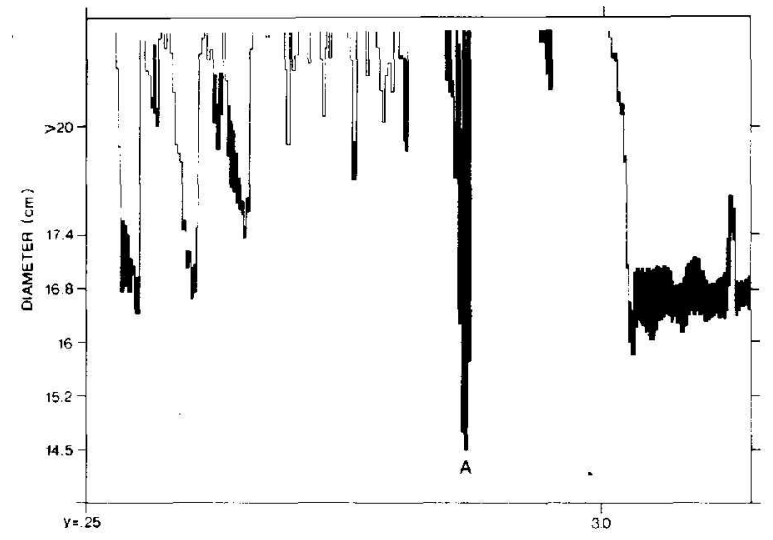

Fig.10. Bore-hole diameter from bed to $1.5 \mathrm{~m}$ above bed in 1979 bore hole. Measurements made in May 1979 and May 1980. "A" is constriction shown in Figure 9. Black shading shows 1979-80 closure. narrowest part of the entire bore hole. The same figure shows how the hole diameter increases exactly at the level where dirt layers slowed drill penetration (Fig.7). While closure rates do vary slightly from one level to another the extrusion level shows a unique closure rate.

\section{CONCLUSIONS}

So far our work has shown no evidence for basal movement of cold-based ice over its bed, i.e. the centre of the hole has not moved. However, we have already concluded (Koerner, in preparation) that the dirty ice at the bottom of the Agassiz ice cap at the top of the flow line is due to basal melt during an ice age much older than the Wisconsin. The ice cap that formed then in northern Ellesmere Island must have been of much greater dimensions than the one developed in Wiscons in times.

\section{ACKNOWLEDGEMENTS}

We thank $P$. Mackinnon, now of World Data Center A for Glaciology, for completing an exhaustive search of various companies before arranging purchase of our down bore-hole TV system. We are also indebted to $\mathrm{S}$. Turner, then of Carleton University Engineering Department, for modifying a single-lens reflex Minolta camera in 1977 to take photographs shown in Figures 1 and 2. Bedford Institute of 0ceanography, Hal ifax, Nova Scotia, Canada, kindly loaned us a video tape-recorder in 1979 and 1980 .

\section{REFERENCES}

Harrison W D Kamb W B 1973 Glacier bore-hole photography. Journat of Glaciology 12 (64): $129-137$

Paterson W S B 1976 Vertical strain-rate measurements in an Arctic ice cap and deductions from them. Journal of Giaciology 17(75): $3-12$

Paterson W S B 1977 Secondary and tertiary creep of glacier ice as measured by borehole closure rates. Reviews of Geophysics and Space Physics 15(1): 47-55

Paterson W S B Koerner R M Fisher D Johnsen $S \mathrm{~J}$ Clausen H B Dansgaard W Bucher $P$ Oeschger H 1977 An oxygen-isotope climatic record from the Devon Island ice cap, Arctic Canada. Wature 266(5602): 508-511 